\title{
QUALITY OF LIFE COMPARISON PRE AND POST SURGERY IN PATIENTS WITH EYE CANCER
}

\author{
Trilaksana Nugroho'), Hari Peni Julianti²) \\ ${ }^{1}$ Department of Ophthalmology, Faculty of Medicine, Universitas Diponegoro, Semarang \\ 2)Department of Public Health-Preventive Medicine, Faculty of Medicine, \\ Universitas Diponegoro, Semarang
}

\begin{abstract}
Background: Quality of life is a global measure, broader than health status, inherently subjective and pertains to all aspects of life important to the person. Patients with eye cancer have to face various problem like visual impairment, anxiety, fear, and depression. These problems can influence the quality of patient life. This study aimed to investigate the quality of life comparison pre and post surgery in patients with eye cancer.

Subjects and Method: This was a retrospective cohort study conducted at Dr. Kariadi Hospital, Semarang, Central Java. A sample of 32 patients with eye cancer was selected for this study by consecutive sampling. The dependent variable was quality of life. The independent variable was surgery status. The data quality of life was obtained by Short Form-36. The other data were collected by a set of questionnaire. Bivariate data analysis was performed by chi square.

Results: Percent of patients with poor quality of life after eye surgery (6.2\%) was lower than percent of patients with poor quality of life before eye surgery (34.4\%), and this increase in quality of life was statistically significant $(\mathrm{p}=0.044)$.

Conclusion: Eye cancer surgery has been shown to be effective in this study to improve the quality of life patients with eye cancer. However, further studies need to be conducted to answer this research question with a randomized control trial design to provide stronger evidence.
\end{abstract}

Keywords: quality of life, surgery, eye cancer

Correspondence:

Trilaksana Nugroho. Department of Ophthalmology, Faculty of Medicine, Universitas Diponegoro, Semarang, Central Java. Email: trilaks@yahoo.com. Mobile: 0811296047

The $6^{\text {th }}$ International Conference on Public Health

Best Western Premier Hotel, Solo, Indonesia, October 23-24, 2019 | 364

https://doi.org/10.26911/the6thicph.05.29 